Available online at GSC Online Press Directory

GSC Biological and Pharmaceutical Sciences

e-ISSN: 2581-3250, CODEN (USA): GBPSC2

Journal homepage: https://www.gsconlinepress.com/journals/gscbps

(RESEARCH ARTIClE)

\title{
Chemical analysis and antibacterial activities of Calotropis procera and Clusia rosea leaves extracts
}

\author{
Abegunde Segun M* , Akinyele Simeon A and Ayodele-Oduola Roseline 0 \\ Department of Science Technology, Federal Polytechnic, Ado-Ekiti, Nigeria.
}

Publication history: Received on 11 June 2020; revised on 04 July 2020; accepted on 06 July 2020

Article DOI: https://doi.org/10.30574/gscbps.2020.12.1.0175

\begin{abstract}
In this work, aqueous and ethanolic extracts of Calotropis procera and Clusia rosea leaves were evaluated for phytochemicals and antibacterial activities in an attempt to evaluate their medicinal potentials. The results of the phytochemical screening showed the presence of alkaloids, saponins, glycosides, tannins, and phenolic compounds in the aqueous extracts of Calotropis procera (AqCp) and Clusia rosea (AqCr), and ethanolic extracts of Calotropis procera (EtCp) and Clusia rosea (EtCr). The concentrations of the bioactive constituents in the extracts were in order AqCp > EtCp > AqCr > EtCr. The antibacterial activities were evaluated against Escherichia coli, Pseudomonas aeruginosa, Staphylococcus aureus, Salmonella typhi and, Streptococcus pyrogenes with different concentration of the plant extracts. The results of the antibacterial evaluations indicate the plant extracts can be used to inhibit the growth of the bacteria with AqCp being more effective. The result of this study validates the use of the aqueous extract of plant extracts in ethnomedicine and this could provide a lead in the isolation of antibacterial agents from water extracts of medicinal plants.
\end{abstract}

Keywords: Calotropis procera; Clusia rosea; Antibacterial activities; Ethnomedicine

\section{Introduction}

For years, nature has been the source of several invaluable medicines and medicinal agents. Medicinal plants are the gifts of nature that are widely employed to treat several ailments. The medicinal properties of these plants are due to the presence of secondary metabolites that produce definite physiological action on the human body [1]. Plants are endowed with the natural ability to synthesize and store a great diversity of bioactive substances [2 - 4] with therapeutic tendencies. Some of these metabolites have been successfully isolated and used in the treatment and prevention of diseases [5]. Among the most essential plants' bioactive chemical components are alkaloids, flavonoids, tannins, terpenoids and phenolic compounds [6]. The roles played by plant bioactive substituents in disease control have been demonstrated by many researchers in recent years.

Calotropis procera belongs to the Asclepiadaceae family. It is popularly known as the desert wick, calotrope, calotropis, dead Sea fruit, giant milk weed in English; bomu bomu in Yoruba; tumfafia in Hausa; Oshar in Sudan; madar, akada, akdo, aak in Hindi; bomba, algodón extranjero in Spanish; mpamba in Swahili; ipekag in Turkish; aalaka in Sanskrit; boah in Somali; wahre mudarpflanzer, gomeiner in German, calotropo in Italian, pomme de sodome in French, mandara in Marathi and kisher, debaj or usher in Arabic [7 - 11]. It is a xerophytic, erect shrub, growing widely throughout the tropical and sub-tropical regions of Asia and Africa [11]. Calotropis procera has considerable potential as a potent medicine in the treatment of leucoderma, leprosy, ulcers, tumors, and piles, diseases of the spleen, liver and abdomen $[12,13]$. The pharmacological effects such as antidiabetic, antimicrobial, anti-inflammatory, renal protective, analgesic and anticancer, anti-angiogenic, immunological, antioxidant, cardiovascular, hepatic protective, antidiarrheal, anticonvulsant, antifertility and enhancement of wound healing by Calotropis procera have been reported [14, 12].

\footnotetext{
* Corresponding author: Abegunde Segun M Email: abegundes@gmail.com
} 
Clusia rosea belongs to the family of Clusiaceae [15]. Clusia rosea, also known as an autograph tree, balsam apple, copey, and pitch-apple, is a tropical and sub-tropical evergreen plant species that can grow up to 18 metres tall [16]. The tree is commonly found in the Caribbean. It is cultivated as an ornamental and street tree. The tree has many local uses and often harvested from the wild for its wood, latex and medicinal applications [17]. The resinous latex obtained from the plant is used medicinally and as a plaster.

Furthermore, members of the Clusia family had shown to have an inhibitory effect on human immunodeficiency virus (HIV) [18 - 20]. Leaves of Clusia sp. Are often used to soften the skin and have a potential benefit in skincare [21]. This work sought to investigate the chemical composition, and antibacterial activities of Calotropis procera and Clusia rosea leaves extracts.

\section{Material and methods}

\subsection{Plant sample collection and preparation}

Fresh leaves of Calotropis procera plant and Clusia rosea were collected from Odo Ado and Government reserve areas of Ado-Ekiti. Both plants were identified and authenticated in the plant science laboratory, Federal Polytechnic, AdoEkiti. The leaves were moved to the laboratory, washed under running water and dried under shield for 10 days. The dried leaf was pulverized with blender, sieved and stored in polythene bags for further analysis. Each plant leaf powdered was extracted separately with water and 95\% ethanol. The extraction was done by soaking $20 \mathrm{~g}$ of each leaf powder in a beaker containing $200 \mathrm{ml}$ of a specific solvent for 48 hours with periodic agitation. After 48 hours, the content of the beaker was filtered using Whitman No. 1 filter paper and the filtrates were concentrated in a water bath at $65{ }^{\circ} \mathrm{C}$. The extracts were stored in different airtight containers, labelled and kept at $4{ }^{0} \mathrm{C}$ until further analysis.

\subsection{Phytochemical Screening}

The phytochemical screening of aqueous and ethanolic extracts of both Calotropis procera and Clusia rosea leaves was done using the methods reported by Abegunde [22].

\subsection{Test organisms}

The microorganisms used for the antibacterial activities are Escherichia coli, Pseudomonas aeruginosa, Staphylococcus aureus, Salmonella typhi, and Streptococcus pyrogenes

\subsection{Antibacterial assay}

The antibacterial assay was performed using a method reported by Bilal et al., [23]. Nutrient agar media used for antibacterial assay were obtained from the microbiology laboratory, Federal polytechnic, Ado-Ekiti. The Agar media were prepared and sterilized at $121^{\circ} \mathrm{C}$ for 20 minutes in an autoclave. The nutrient agar media were transferred into a separate sterilized petri dish in laminar air flow, allowed it to cool and then solidified. Bacterial culture was inoculated through the cotton swab method. After the inoculation and uniform distribution of bacteria on the surface of the media, prepared discs with different plant extract concentrations $(0.5,1.0,1.5,2.0$ and $2.5 \mathrm{mg} / \mathrm{L})$ were impregnated on the surface of the media using forceps and the Petri dishes were transferred to an incubator for incubation. The incubation was done at $37^{\circ} \mathrm{C}$ for 24 hours and the zone of inhibition was measured using a transparent meter ruler and recorded.

\section{Results and discussion}

\subsection{Phytochemical screening results}

The results of the phytochemical examinations of aqueous and ethanolic extracts of Calotropis procera and Clusia rosea leaves are presented in Table 1. The availability of the bioactive materials in plant extracts depends on the solvent used. This is because of the degree of solubility of the bioactive constituents in a different solvent. The results revealed the presence of alkaloids, saponins, glycosides, tannins and phenolic compounds in the aqueous and ethanolic extracts of both plants. Terpenoids were present in the extracts of Calotropis procera and its aqueous extract revealed the presence of flavonoids. However, both flavonoids and terpenoids were absent in the extracts of Clusia rosea using alkaline reagent test and Salkowki's test respectively. From Table 1, the aqueous solvent can be said to be more effective for the extraction of bioactive materials. This result was similar to the report of Abegunde and Ayodele-Oduola [11]. Tanninsriched plant extracts are known to exhibit strong antimicrobial activity by preventing the much-needed protein from being available for the organism and facilitate the precipitation of microbial protein [24]. Furthermore, saponin has been reported with expectorant activity on both gram-positive and gram-negative bacteria $[6,25,26]$. 
Table 1 Result of phytochemical screening of aqueous and ethanolic extracts of Calotropis procera and Clusia rosea leaves.

\begin{tabular}{|c|c|c|c|c|c|c|c|c|}
\hline \multirow[b]{2}{*}{ Plant } & \multirow[b]{2}{*}{ Solvent } & \multirow{2}{*}{$\begin{array}{l}\text { Alkaloids } \\
\text { Wagner's } \\
\text { test }\end{array}$} & \multirow{2}{*}{$\begin{array}{l}\text { Saponins } \\
\text { Foam test }\end{array}$} & \multirow{2}{*}{$\begin{array}{l}\text { Flavonoids } \\
\begin{array}{l}\text { Alkaline } \\
\text { reagent test }\end{array}\end{array}$} & \multirow{2}{*}{$\begin{array}{l}\text { Terpenoids } \\
\begin{array}{l}\text { Salkowki's } \\
\text { test }\end{array}\end{array}$} & \multirow{2}{*}{$\begin{array}{l}\text { Glycosides } \\
\text { Keller } \\
\text { Kelliani's } \\
\text { test }\end{array}$} & \multirow{2}{*}{$\begin{array}{l}\text { Tannins } \\
\text { Braymer's } \\
\text { test }\end{array}$} & \multirow{2}{*}{$\begin{array}{l}\text { Phenolic } \\
\text { Compounds } \\
\begin{array}{l}\text { Ferric } \\
\text { chloride test }\end{array}\end{array}$} \\
\hline & & & & & & & & \\
\hline \multirow{2}{*}{$\begin{array}{l}\text { Calotropis } \\
\text { procera }\end{array}$} & Aqueous & ++ & ++ & ++ & ++ & ++ & ++ & + \\
\hline & Ethanol & ++ & ++ & - & ++ & ++ & ++ & + \\
\hline \multirow{2}{*}{$\begin{array}{l}\text { Clusia } \\
\text { rosea }\end{array}$} & Aqueous & ++ & + & - & - & ++ & + & + \\
\hline & Ethanol & ++ & ++ & - & - & + & + & + \\
\hline
\end{tabular}

\subsection{Antibacterial activity results}

The results of the antibacterial activity of the aqueous and ethanolic extracts of Calotropis procera and Clusia rosea leaves were measured in terms of the diameter of the zone of inhibition and presented in Figure $1-5$. Figures 1, 2, 3, 4 and 5 represent the performances of the aqueous and ethanolic extracts of Calotropis procera and Clusia rosea leaves to inhibit the development of Escherichia coli, Pseudomonas aeruginosa, Staphylococcus aureus, Salmonella typhi and Streptococcus pyrogenes respectively at different concentrations. The results revealed that the extracts are effective as inhibition agents against the bacteria. This result supported earlier report by Farooq et al., [27] that extracts of plants are potent against some bacteria. However, the performances increased with an increase in the concentration of each extract. Generally, the aqueous extract of Calotropis procera was more effective against all bacteria while ethanolic extract of Clusia rosea showed the least potency against the bacteria at each concentration dose. The result of the present work justifies the use of an aqueous extract of $C$. procera in ethnomedicine for the treatment of infectious diseases caused by bacteria [28]. The highest performance of $24.80 \pm 20$ was recorded for $2.5 \mathrm{mg} / \mathrm{ml}$ aqueous extract of Calotropis procera against Escherichia coli. Escherichia coli showed the most susceptibility to the plant extracts while Salmonella typhi showed the least susceptibility to the plant extracts.

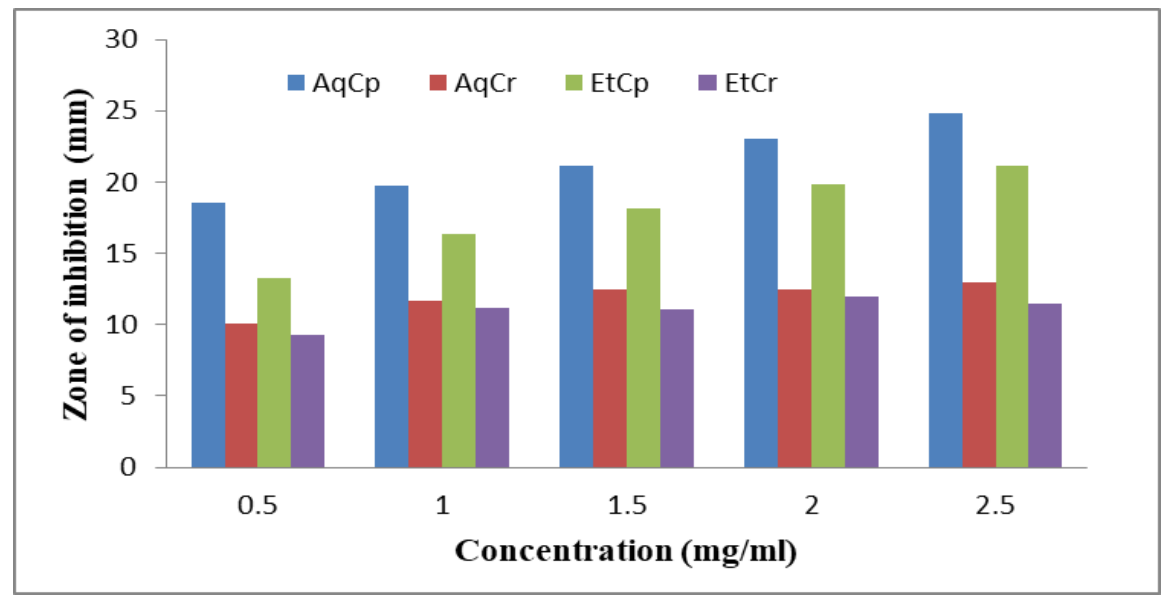

Figure 1 Diameter of the inhibition zone on the growth of Escherichia coli against aqueous and ethanolic leaves extracts of Calotropis procera and Clusia rosea at different concentration 


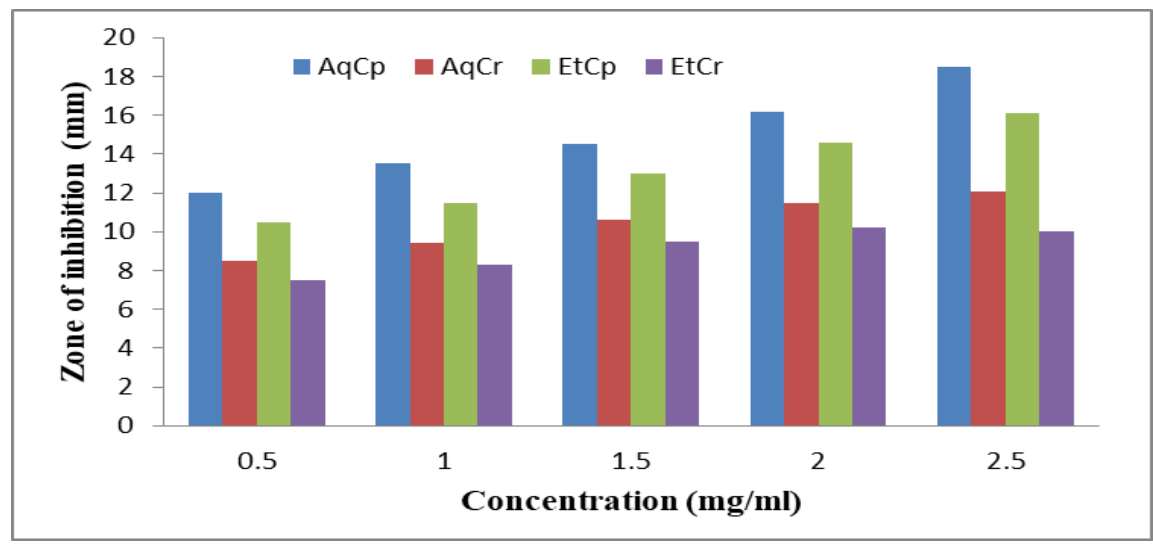

Figure 2 Diameter of the inhibition zone on the growth of $P$. aeruginosa against aqueous and ethanolic leaves extracts of Calotropis procera and Clusia rosea at different concentration

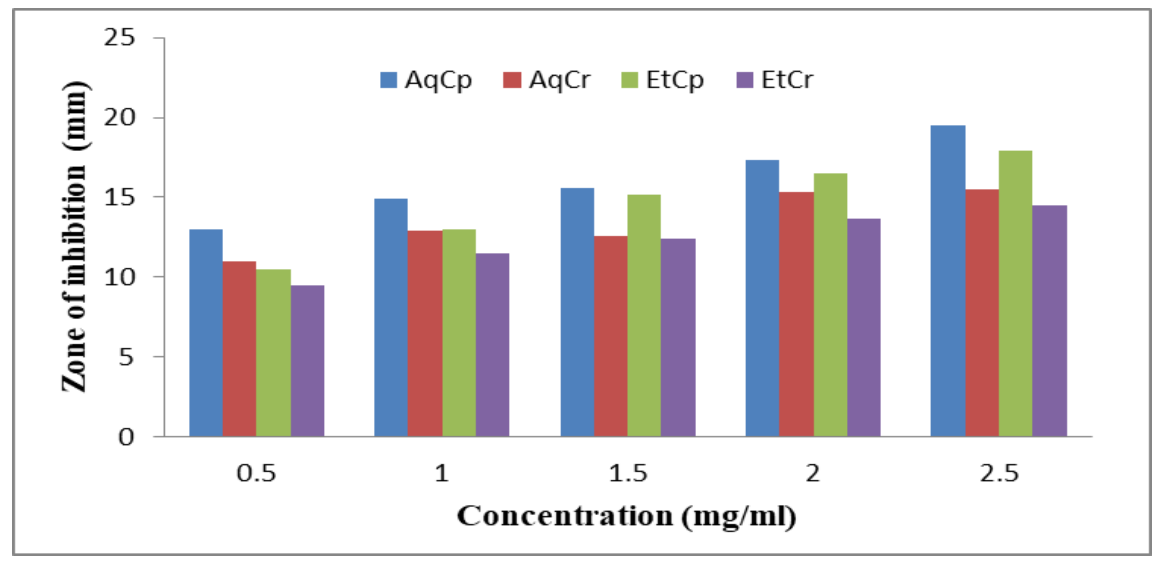

Figure 3 Diameter of the inhibition zone on the growth of S. aureus against aqueous and ethanolic leaves extracts of Calotropis procera and Clusia rosea at different concentration

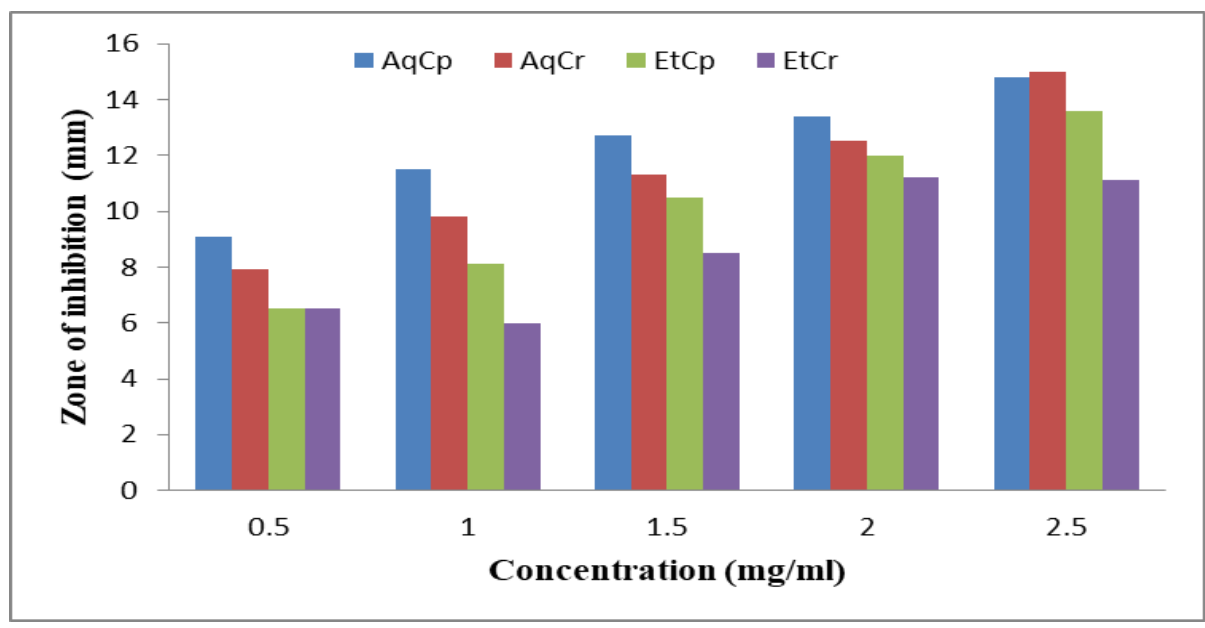

Figure 4 Diameter of the inhibition zone on the growth of Salmonella typhi against aqueous and ethanolic leaves extracts of Calotropis procera and Clusia rosea at different concentration 


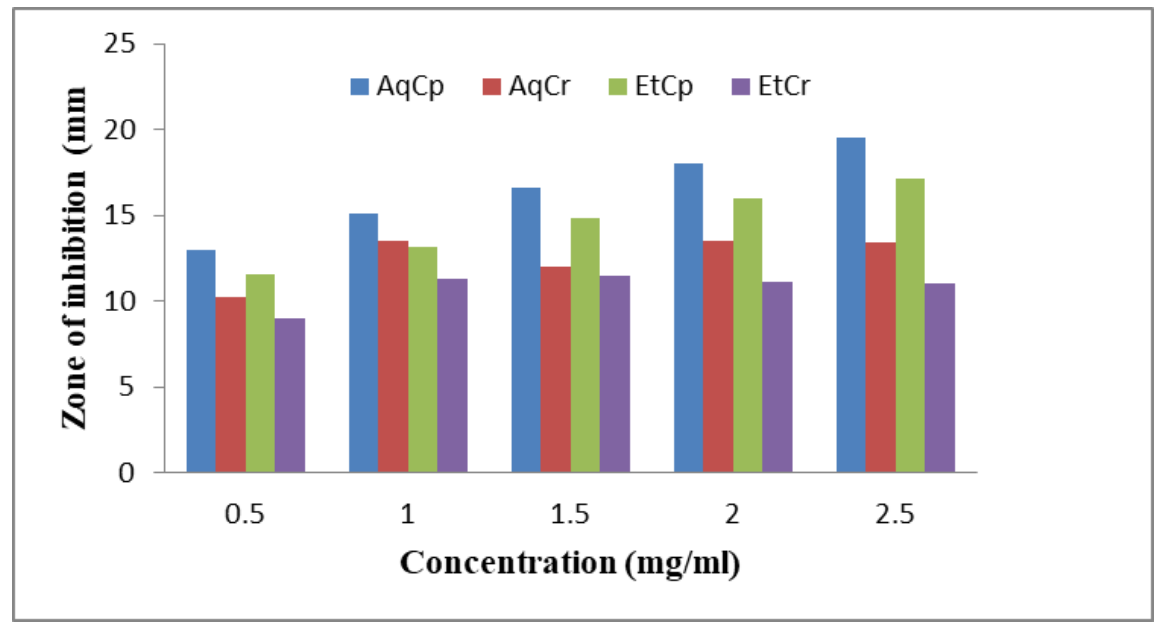

Figure 5 Diameter of the inhibition zone on the growth of $S$. pyogenes against aqueous and ethanolic leaves extracts of Calotropis procera and Clusia rosea at different concentration

\section{Conclusion}

The successful phytochemical screening of aqueous and ethanolic extracts of Calotropis procera and Clusia rosea revealed the presence of some bioactive constituents. The results of the antimicrobial activities have shown that aqueous and ethanolic extracts of Calotropis procera and Clusia rosea leaves inhibit the growth of some bacteria. The inhibitory tendency increased with increase extract dosage. It could, therefore, be concluded that the extracts of both plants can be used to retard the growth of some bacteria.

\section{Compliance with ethical standards}

\section{Acknowledgments}

The authors appreciate the financial support of TETFUND-IBR, Nigeria.

\section{Disclosure of conflict of interest}

There is no conflict of interest in publishing the present data of the study.

\section{References}

[1] Akinmoladun AC, Ibukun EO, Afor E, Obuotor EM and Farombi EO. (2007). Phytochemical constituent and antioxidant activity of extract from leaves of Ocimum gratissimum. Scientific Research Essay, 2, 163 - 166.

[2] Geissman TA. (1963). Flavonoid, Compound, Tannis, Lignins, and compounds, In: Florkin, M and EH Stotz (ed.) Pyrrole Pigments, Isoprenoid Compounds and Phenolic Plants Constitutes, 9.

[3] Tugbobo OS, Abegunde SM, Awonegan PA, Akinyede KA and Oyewusi HA. (2020). Dietary protection by Tapinanthus globiferus (Mistletoe) leaf extract against prontosil-induced clastogenicity in mice in vivo. GSC Biological and Pharmaceutical Sciences, 10(3), 160-163.

[4] Samuel T, Michael A and Solomon I. (2018). Genomic Modification by Ocimum canum Against Lead-Induced Chromosome Aberration and Its Effect on Antioxidant Enzymes. Journal of Advanced Research in Medical Science \& Technology, 4 (3\&4), 1-4.

[5] Hieh Y and Turner CH. (2001). Effects of Loading Frequency on Mechanically Induced Bone Formation. Journal of Bone and Mineral Research, 16(5).

[6] Shobowale 00, Ogbulie NJ, Itoandon EE, Oresegun MO and Olatope SOA. (2013). Phytochemical and Antimicrobial Evaluation of Aqueous and Organic Extracts of Calotropis procera Ait Leaf and Latex. Nigerian Food Journal, 31(1), 77 - 82.

[7] Gupta S, Bhawani G, Karishma K and Pooja S. Ehnopharmaological potential of Calotropis procera : An overview. International Research Journal of Pharmac, 3(12), $19-22$. 
[8] Orwa C, Mutua A, Kindt R, Jamnadass R and Simons A. (2009) Agroforestree Database: a tree reference and selection guide version.

[9] Sharma AK, Kharb R and Kaur R. (2011). Pharmacognostical aspects of Calotropis procera (Ait.) R. Br. International Journal of Pharma and Bio Sciences, 2(3), 480 - 488.

[10] Agbogidi OM, Onosode AT and Okonta BC. (2006). Susceptibility of Dennettia tripetala (Bak.) F. seeds to crude oil. Journal of Food, Agriculture and Environment, 4(2), 350-352.

[11] Abegunde SM and Ayodele-Oduola RO. (2015). Comparison of efficiency of different solvents used for the extraction of phytochemicals from the leaf, seed and stem bark of Calotropis Procera, International Journal of Science and Research, 4(7), 835 - 838.

[12] Ahmed KM, Rana A and Dixit V. (2004). Effect of Calotropis procera latex on isoproterenol induced myocardial infarction in albino rats. Phytomedicine, 11(4), 327 - 330.

[13] Samuel T, Michael A, Solomon I and Ademola O. (2018). Inhibitory Effect of Lime on Arsenic-Induced Lipid Peroxidation in Growing Rice Plants. Journal of Advanced Research in Medical Science \& Technology, 5(1), 1 - 5.

[14] Odugbemi T and Akinsulire 0. (2006). Medicinal plants according to family names. In: Odugbemi, T. (ed). Outlines and Pictures of Medicinal Plants from Nigeria, University of Lagos Press, Akoka, Yaba, Nigeria, 81.

[15] Stevens P. (2007). Clusiaceae-Guttiferae. Flower. Plants Eudicots, 255.

[16] Little EL and Wadsworth FH. (1964). Common Trees of Puerto Rico and the Virgin Islands. USDA, Forest Service; Washington.

[17] Arthur WA. (2000). Tropical Ornamentals; A Guide, Timber Press Inc. Oregon.

[18] Bailón-Moscoso N, Romero-Benavides JC, Sordo M, Villacís J, Silva R, Celi L, Martínez-Vázquez M and OstroskyWegman P. (2016). Phytochemical study and evaluation of cytotoxic and genotoxic properties of extracts from Clusia latipes leaves. Brazilian journal of pharmacognosy, 26, 44-49.

[19] Huerta-Reyes M, Basualdo MDC, Lozada L, Jimenez-Estrada M, Soler C and Reyes-Chilpa R. (2004). HIV-1 inhibition by extracts of Clusiaceae species from Mexico. Biological and Pharmaceutical Bulletin, 27, 916 - 920.

[20] Balunas MJ and Kinghorn AD. (2005). Drug discovery from medicinal plants. Life Science, 78, $431-441$.

[21] Valadeau C, Castillo JA, Sauvain M, Lores AF and Bourdy G. (2010). The rainbow hurtsmy skin: medicinal concepts and plants uses among the Yanesha (Amuesha), an Amazonian Peruvian ethnic group. Journal of Ethnopharmacology, 127, 175 - 192.

[22] Abegunde SM. (2018). Proximate Composition, Phytochemical Analysis and Elemental Characterization of Raphia taedigera Seed. Asian Journal of Chemical Sciences, 5(2), 1 - 8.

[23] Bilal H, Ali I, Uddin S, Khan I, Said A, Rahman M, Khan A, Shah A and Khan AA. (2020). Biological evaluation of antimicrobial activity of Calotropis procera against a range of bacteria. Journal of Pharmacognosy and Phytochemistry, 9(1), 31-35.

[24] Sodipo OA, Akanji MA, Kolawole FB and Odutuga AA. (1991). Saponin is the active antifungal principle in Garcinia kola, heckle seed. Bioscience Research Communications, 3, 171 - 171.

[25] Ashafa AOT and Afolayan AJ. (2009). Assessment of the antimicrobial activity of the root extracts from Chrysocoma ciliata L. African Journal of Microbiology Research, 3(11), 700 - 703.

[26] Ogbulie JN, Ogueke CC, Okoli LC and Anyanwu BN. (2007). Antibacterial activities and toxicological potential of crude ethanolic extract of euphorbia hirta. African Journal of Biotechnology 6 (13), 1544 - 1548.

[27] Farooq U, Nisar S, Merzaia AB and Azeem MW. (2017). Isolation of Bioactive components from Calotropis procera Plant Latex-A Review._International Journal of Chemical and Biochemical Science, 11, 95-101.

[28] Mainasara MM, Aliero BL, Aliero AA and Dahiru SS. (2011). Phytochemical and Antibacterial Properties of Calotropis Procera (Ait) R. Br. (Sodom Apple) Fruit and Bark Extracts. International Journal of Modern Botany, 1(1), $8-11$.

\section{How to cite this article}

Abegunde SM, Akinyele SA and Ayodele-Oduola RO. (2020). Chemical analysis and antibacterial activities of Calotropis procera and Clusia rosea leaves extracts. GSC Biological and Pharmaceutical Sciences, 12(1), 25-30. 